\title{
Effect of negative ionisation of inspired air on the response of asthmatic children to exercise and inhaled histamine
}

\author{
I BEN-DOV, I AMIRAV, M SHOCHINA, I AMITAI, E BAR-YISHAY, S GODFREY \\ From the Pulmonary Function Laboratory and Department of Pediatrics, Hadassah University Hospital, \\ Mount Scopus, Jerusalem, Israel
}

ABSTRACT To evaluate the effect of negative ionisation of inspired air on bronchial reactivity, $11 \stackrel{\infty}{\perp}$ asthmatic children were challenged twice by exercise and 10 were challenged twice by histamine $\stackrel{\circ}{工}$ inhalation. The children breathed negatively ionised air $\left(4 \times 10^{5}-10 \times 10^{5} \mathrm{ions} / \mathrm{cm}^{3}\right)$ or control $\overrightarrow{>}$ room air in random order in a double-blind fashion. All challenges were matched in terms of basal lung function and the exercise tests were matched in terms of ventilation and respiratory $\frac{{ }_{0}}{\omega}$ heat loss. Exercise-induced asthma was significantly attenuated by exposure to negatively ionised $\vec{\bullet}$ air, the mean postexercise fall in one-second forced expiratory volume $\left(\mathrm{FEV}_{1}\right)$ being $29 \%\left(\mathrm{SE}_{\mathrm{\omega}}^{\infty}\right.$ $5 \%)$ of the initial value after the control and $21 \%(3 \%)$ after the ionised air test $(p<0.02)$. Ten of the 11 subjects developed less exercise-induced asthma while breathing ionised air. Althougho the median dose of histamine (cumulative breath units) which caused a constant fall in $\mathrm{FEV}_{1}$ for each individual was higher with the ionised air challenge than with the control challenge the difference was not significant. Five of the 10 subjects were less sensitive to histamine and the $\frac{\Phi}{\mathscr{Q}}$ other five more sensitive when breathing ionised air. It is concluded that negative ionisation of $\overrightarrow{\vec{A}}$ inspired air can modulate the bronchial response to exercise but the effect on the response to histamine is much more variable.

Asthmatic patients show increased airway responsiveness when exposed to various stimuli, both specific stimuli such as antigen inhalation and nonspecific ones such as histamine inhalation or physical exertion. ${ }^{1-4}$ The factors influencing bronchial hyperreactivity have recently been reviewed by Boushey et al. ${ }^{4}$ Among other factors, the condition of the respired air is important and it has been shown that warm, humid air attenuates the response to exercise..$^{56}$

The ionic charge of the air has long been thought to affect various biological systems, ${ }^{78}$ including the respiratory system..$^{910}$ Ionisation might particularly affect asthmatic people owing to their considerable bronchial lability. Uncontrolled studies in the past have suggested a beneficial effect of negative ions on

Address for reprint requests: Professor S Godfrey, Department of Pediatrics, Hadassah University Hospital, Mount Scopus, Jerusalem, Israel.

Accepted 29 March 1983 lung function in asthmatics, but the observed changes were always minor. ${ }^{112}$ To investigate this further we have studied the response of asthmatic children to exercise and inhaled histamine while breathing negatively ionised air under controlled conditions.

\section{Methods}

Seventeen asthmatic patients, 11 boys and six girls with a mean age of 12.5 years (range 10-20 years) participated in this study. All were known to haven had asthmatic attacks provoked by physical exer tion. Children and parents gave informed consent to the tests after a full explanation of the procedure The patients refrained from taking sympathomime $=$ tic medication or sodium cromoglycate for an least 12 hours and long-acting theophylline for $24_{0}$ hours before any test. Inhaled steroids were con ${ }^{\circ}$ tinued at the same level throughout the test. Bron $\vec{D}$ chial reactivity was evaluated by either one or tw types of bronchial provocation, exercise or his $\frac{}{-}$ tamine inhalation. Each challenge was undertaken 
twice, with and without exposure to negatively charged inspired air, in a double-blind fashion in randomised order. Subjects breathed the specific test gas through a low-resistance one-way valve. During the exercise tests cold, dry air was inhaled from an insulated reservoir. Air was cooled by a simple refrigerator unit and dried by passing it through a calcium chloride chamber. During the histamine challenge tests room air $\left(22-25^{\circ} \mathrm{C}, 46-52 \%\right.$ relative humidity) was breathed through the circuit.

Ions were produced by a generator with a negligible ozone production $(<0.05 \mathrm{ppm})$ operating by application of an appropriate electrostatic charge to plates over which air passed (Modulion System, Amcor, Israel). This generator was connected in the inspired air line upstream from the valve box so that all the inspired air passed over the plates and the ions were carried to the mouthpiece by the inspired air. The ion concentration measured at the mouthpiece (Kathrein Ionometer M6K 01) for each individual was constant and ranged from $5 \times 10^{5}$ to 10 $\times 10^{5}$ ions $/ \mathrm{cm}^{3}$ during the exercise tests and from 4 $\times 10^{5}$ to $5 \times 10^{5}$ ions $/ \mathrm{cm}^{3}$ during the histamine challenge tests. The ion generator was silent in operation and was left in the circuit during all experiments. A member of the laboratory staff, who had nothing to do with the study, was responsible for either turning the generator on or leaving it off in random fashion, without the knowledge of those concerned.

Expired air was directed to a mixing chamber and pneumotachygraph coupled with a gas analyser (PK Morgan Exercise Test System, England), which enabled ventilation and gas exchange to be continuously recorded during the exercise tests. Lung function was measured with the aid of a pulmonary calculator system (Vanguard DS500, Massachusetts), connected to the expiratory side of the circuit in such a way as to enable the subject to breath the test gas throughout even during lung function testing. Expired air temperature was recorded by a highresponse thermistor (Model 530 Yellow Spring Instruments $\mathrm{Co}$ ) located at the mouthpiece and the inspired air temperature by a bulb thermometer located in the inspiratory line $5 \mathrm{~cm}$ from the mouthpiece.

\section{EXERCISE PROVOCATION TESTS}

Eleven subjects (Nos 1-11, table 1) undertook two identical six minute exercise tests, 3-24 hours apart, using a cycle ergometer (Lode Instruments, NV). The work load was calculated to represent about two-thirds of the maximal predicted oxygen consumption for each individual. When measured at the mouthpiece the inspired air temperature was $9.8^{\circ}$ (SE $0.5^{\circ} \mathrm{C}$ ) and the water content, determined by wet and dry bulb hygrometry, was $3.8(0.4) \mathrm{mg}$ $\mathrm{H}_{2} \mathrm{O} / 1$. Respiratory heat loss was calculated on the basis of the equation of Deal et al. ${ }^{6}$

Lung function was measured at the start of any test day, after five minutes of breathing the cold dry test gas and after 10 minutes of exposure to either the ionised air or the control non-ionised air just before starting the exercise. Measurements were made after three minutes of exercise and at intervals for 30 minutes after the exercise test. The best forced expired volume in one second $\left(F E V_{1}\right)$ obtained in two or three attempts was recorded for each measurement. The test gas was inhaled continuously and measurements were continued until the $\mathrm{FEV}_{1}$ returned to $\pm 10 \%$ of the pre-exercise value.

Bronchoconstriction after exercise was expressed

Table 1 Data on the patients studied

\begin{tabular}{|c|c|c|c|c|c|c|}
\hline Subject No & Sex & $\begin{array}{l}\text { Age } \\
(y)\end{array}$ & $\begin{array}{l}\text { Height } \\
\text { (cm) }\end{array}$ & $\begin{array}{l}\text { Weight } \\
(\mathrm{kg})\end{array}$ & $\begin{array}{l}\text { No of positive } \\
\text { skin tests }\end{array}$ & $\begin{array}{l}\text { Regular } \\
\text { treatment }\end{array}$ \\
\hline $\begin{array}{r}1 \\
2 \\
3 \\
4 \\
5 \\
6 \\
7 \\
8 \\
9 \\
10 \\
11 \\
12 \\
13 \\
14 \\
15 \\
16 \\
17 \\
\end{array}$ & $\begin{array}{l}\mathbf{M} \\
\mathbf{M} \\
\mathbf{M} \\
\mathbf{M} \\
\mathbf{M} \\
\mathbf{M} \\
\mathbf{F} \\
\mathbf{M} \\
\mathbf{M} \\
\mathbf{M} \\
\mathbf{F} \\
\mathbf{F} \\
\mathbf{M} \\
\mathbf{F} \\
\mathbf{F} \\
\mathbf{F} \\
\mathbf{M}\end{array}$ & $\begin{array}{l}11 \\
14 \\
10 \\
11 \\
12 \\
13 \\
10 \\
13 \\
15 \\
14 \\
10 \\
11 \\
13 \\
10 \\
14 \\
20 \\
11\end{array}$ & $\begin{array}{l}142 \\
155 \\
135 \\
139 \\
137 \\
137 \\
141 \\
159 \\
162 \\
146 \\
140 \\
140 \\
137 \\
146 \\
154 \\
150 \\
132\end{array}$ & $\begin{array}{l}35 \\
38 \\
27 \\
30 \\
29 \\
35 \\
31 \\
46 \\
50 \\
38 \\
37 \\
32 \\
35 \\
36 \\
35 \\
40 \\
31\end{array}$ & $\begin{array}{l}1 \\
0 \\
0 \\
3 \\
2 \\
3 \\
0 \\
4 \\
0 \\
1 \\
0 \\
0 \\
3 \\
0 \\
2 \\
0 \\
0\end{array}$ & $\begin{array}{l}\text { ISB, HDT } \\
\text { ISB } \\
\text { ISB, BDP } \\
\text { ISB } \\
\text { ISB } \\
\text { ISB, BDP } \\
\text { ISB, HDT } \\
\text { ISB } \\
\text { ISB, SCG } \\
\text { ISB, BDP } \\
\text { ISB } \\
\text { BDP } \\
\text { BDP } \\
\text { BDP } \\
\text { ISB, BDP } \\
\text { ISB, SCG } \\
\text { ISB, SCG }\end{array}$ \\
\hline
\end{tabular}

ISB —intermittent sympathomimetic bronchodilator; HDT—high-dose theophylline; BDP—beclomethasone dipropionate; SCG-sodium cromoglycate. 
as the maximum percentage fall in $\left.\mathrm{FEV}_{1}(\triangle \mathrm{FEV})_{1}\right)$ from the baseline value recorded after 10 minutes of exposure to the ionised or non-ionised cold dry gas just before cycling.

\section{HISTAMINE PROVOCATION TESTS}

Ten subjects (Nos 8-17, table 1) undertook two histamine challenge tests 24 hours apart, according to the protocol described by Chai et al. ${ }^{13}$ Four of these subjects (Nos 8-11) had also taken part on a previous occasion in the exercise challenge study. For the histamine test the subject inhaled five vital capacity breaths of buffered phosphate as control followed by dilutions of histamine phosphate, the starting concentration being $0.03 \mathrm{mg} / \mathrm{ml}$ and concentrations then doubling up to a maximum of $10 \mathrm{mg} / \mathrm{ml}$. Histamine was nebulised by a Hudson nebuliser with air supplied at $20 \mathrm{lb} / \mathrm{in}^{2}(138 \mathrm{kPa})$, and delivered to the circuit described above upstream from the inspiratory valve and between the ion generator and the valve box. Baseline lung function was obtained before and after 10 minutes of exposure to ionised or control non-ionised room air breathed through the circuit. The inhalation of the test gas was continued and measurements were made after buffer inhalation and three minutes after inhalation of each histamine concentration until a fall of $20 \%$ or more in $\mathrm{FEV}_{1}$ was recorded or until the maximum concentration of histamine that did not provoke systemic symptoms $(10 \mathrm{mg} / \mathrm{ml})$ was reached. The provocative dose expressed as breath units (1 unit $=1$ breath of $1 \mathrm{mg} / \mathrm{ml}$ histamine base) that caused a $20 \%$ fall in $\mathrm{FEV}_{1}\left(\mathrm{PD}_{20}\right)$ was then calculated from a semilogarithmic plot of the individual dose-response curve. Three subjects reached a histamine concentration of $10 \mathrm{mg} / \mathrm{ml}$ without their $\mathrm{FEV}_{1}$ having fallen by $20 \%$. In these subjects we recorded the histamine dose which caused the maximum fall in $F E V_{1}$, although this was less than a $P_{20}$. This same fall in $\mathrm{FEV}_{1}$ was used as the target for the other histamine challenge (ionised air or control, depending on which was performed first). For convenience the end-point histamine dose will be referred to as the provocative dose (PD) whether the actual fall in $\mathrm{FEV}_{1}$ was $20 \%$ (six subjects) or 14-15\% (three subjects).

The significance of differences was estimated with Student's $t$ test for paired samples and a difference was considered significant if $p<0.05$.

\section{Results}

EXERCISE PROVOCATION TESTS

Mean values of baseline FEV , and of various indices recorded during the exercise tests are shown in table 2. None of the differences between the results of the
Table 2 Mean values (SE) of prechallenge FEV and other: indices recorded during the control and ionised-air exercisecs? tests

\begin{tabular}{|c|c|c|}
\hline & Control & Ionised air \\
\hline Pre-exercise FEV, (l) & $\begin{array}{c}1.36 \\
(0 \cdot 10)\end{array}$ & $\begin{array}{c}1.35 \\
(0 \cdot 08)\end{array}$ \\
\hline $\mathrm{FEV}_{1}$ (\% predicted) & $\begin{array}{l}61 \\
(5)\end{array}$ & $\begin{array}{l}61 \\
(4)\end{array}$ \\
\hline Ventilation $\left(1 \min ^{-1}\right)$ & $\begin{array}{l}48 \cdot 5 \\
(2 \cdot 9)\end{array}$ & $\begin{array}{l}49 \cdot 9 \\
(4 \cdot 2)\end{array}$ \\
\hline $\begin{array}{l}\text { Oxygen consumption } \\
\left(\mathrm{mmol} \mathrm{min}^{-1} \mathbf{k g}^{-1}\right)\end{array}$ & $\begin{array}{l}1.67 \\
(0.18)\end{array}$ & $\begin{array}{c}1.57 \\
(0.18)\end{array}$ \\
\hline Heart rate (beats/min) & 164 & 164 \\
\hline $\begin{array}{l}\text { Respiratory heat loss } \\
\left(\mathrm{J}_{\left.\text {min }^{-1}\right)}\right.\end{array}$ & $\begin{array}{c}0.206 \\
(0.017)\end{array}$ & $\begin{array}{c}0.220 \\
(0.017)\end{array}$ \\
\hline
\end{tabular}

test in which ionised air was breathed and the con $\stackrel{\infty}{+}$ trol test was significant. Breathing ionised air for 109 minutes did not significantly change baseline lungfunction (mean $\mathrm{FEV}_{1}=1.37(0.07 \mathrm{SEM}$ ) and 1.3 $(0.08)$ before and after exposure).

Individual values of $\triangle \mathrm{FEV}_{1}$ after both exercise $\stackrel{\text { क }}{?}$ challenges are presented in table 3 . Exercise $\vec{\imath}$ induced asthma was significantly attenuated in the test in which negatively ionised air was breathed during exercise $(p<0 \cdot 015)$. All subjects except one (No 1) had less exercise-induced asthma while breathing ionised air. In contrast, the mean values of then percentage rise in $\mathrm{FEV}_{1}$ during exercise recordeco after three minutes of cycling were not significantly? different in the control and ionised-air tests-13\% (SE $4 \%$ ) and $15 \%(4 \%)$ respectively. There was no correlation between the protection exerted by nega tive ions and the baseline pre-exercise $\mathrm{FEV}_{1}$ or the severity of the exercise-induced asthma as judged by the $\triangle F E V_{1}$ in the contol challenge.

HISTAMINE PROVOCATION TESTS

The individual values of prechallenge baseline FEV as well as the PD for histamine are given in table 4. The mean baseline FEV, was similar for the controb

Table 3 Individual values for the fall in FEV $(\%)$ in the control and ionised air exercise tests

\begin{tabular}{|c|c|c|}
\hline Subject No & Control & Ionised air \\
\hline $\begin{array}{r}1 \\
2 \\
3 \\
4 \\
5 \\
6 \\
7 \\
8 \\
9 \\
10 \\
11\end{array}$ & $\begin{array}{l}12 \\
20 \\
55 \\
17 \\
53 \\
30 \\
33 \\
12 \\
25 \\
45 \\
16\end{array}$ & $\begin{array}{r}22 \\
10 \\
21 \\
12 \\
45 \\
21 \\
25 \\
8 \\
18 \\
37 \\
11\end{array}$ \\
\hline $\begin{array}{l}\text { Mean } \\
\text { SE }\end{array}$ & $\begin{array}{r}29 \\
5\end{array}$ & $\begin{array}{r}21 \\
3\end{array}$ \\
\hline
\end{tabular}


Table 4 Individual values of prechallenge $F E V_{1}$ presented as percentages of the predicted normal and $P D^{*}$ for the control and ionised-air histamine challenge tests

\begin{tabular}{|c|c|c|c|c|c|}
\hline & \multicolumn{2}{|l|}{ Control } & \multirow{2}{*}{$\underset{\text { with } P b^{*}}{\triangle F E V^{(\%)}}$} & \multicolumn{2}{|l|}{ Ionised air } \\
\hline & $\begin{array}{l}F E V_{1} \\
\text { (\% predicted) }\end{array}$ & $\begin{array}{l}\text { PD } \\
\text { (breath units) }\end{array}$ & & $\begin{array}{l}\text { FEV } \\
\text { (\% predicted) }\end{array}$ & $\begin{array}{l}P D \\
\text { (breath units) }\end{array}$ \\
\hline $\begin{array}{l}8 \\
9 \\
10 \\
11 \dagger \\
12 \\
13 \\
14 \\
15 \\
16 \\
17\end{array}$ & $\begin{array}{r}42 \\
43 \\
77 \\
115 \\
92 \\
70 \\
62 \\
77 \\
75 \\
94\end{array}$ & $\begin{array}{r}13.50 \\
3.40 \\
10.00 \\
>137 \\
35.00 \\
13.05 \\
2.05 \\
0.20 \\
22.00 \\
132.00\end{array}$ & $\begin{array}{l}20 \\
20 \\
20 \\
\left(\frac{-}{15}\right) \\
14 \\
20 \\
20 \\
20 \\
14\end{array}$ & $\begin{array}{r}51 \\
43 \\
65 \\
102 \\
89 \\
72 \\
68 \\
72 \\
66 \\
93\end{array}$ & $\begin{array}{r}0.64 \\
72.00 \\
2.30 \\
98.00 \\
132.00 \\
132.00 \\
36.00 \\
9.20 \\
14.00 \\
96.00\end{array}$ \\
\hline $\begin{array}{l}\text { Mean }(n=9) \\
\text { SE }\end{array}$ & $\begin{array}{r}70 \\
6\end{array}$ & median 13.05 & $\begin{array}{r}18 \\
1\end{array}$ & $\begin{array}{r}69 \\
5\end{array}$ & median 36 \\
\hline
\end{tabular}

*The provocative dose of histamine causing a $20 \%$ fall in $\mathrm{FEV}_{1}$ or, in three cases, the maximum fall (which was less than $20 \%$ ).

tNot included in the calculation of the mean and median values because there was no fall in FEV, in the control test.

$\triangle F E V_{1}(\%)$-percentage fall in $\mathrm{FEV}_{1}$ achieved in each challenge.

and ionised-air tests. The median provocative dose of histamine was higher during the challenge performed during the breathing of ionised air than during the control test-55 (18) and $26(14)$ breath units respectively. There was very considerable variation between the subjects, however, and this difference did not reach significance. One subject (No 11) failed to develop any fall in $\mathrm{FEV}_{1}$ during the control test despite receiving the maximum dose of histamine but developed a $20 \%$ fall in the ionised air test.

Five subjects (Nos 9 and 12-15: table 4) were less sensitive to histamine while breathing negative ions and four subjects (Nos $8,10,16,17)$ were more sensitive with ionisation. Clearly subject No 11 was also worse with ionised air but his PD could not be calculated. These two groups were not different from each other in terms of their mean age, baseline prechallenge $\mathrm{FEV}_{1}$, or the presence or absence of atopy as shown by the number of positive skin test responses.

\section{Discussion}

The results show that negatively ionised inspired air reduced exercise-induced bronchial reactivity in all but one of the patients tested. The concentration of ions in the mouthpiece was, however, about 100 times the natural concentration. Previous uncontrolled studies using a lower concentration of ions ${ }^{10-12}$ have in general shown a slight improvement in resting lung function in infants and patients with asthma. We were unable to show any such change in resting lung function in our studies, which were performed in a carefully controlled, double-blind fashion.
The effect of ionised air on the sensitivity to inhaled histamine was inconclusive, with some subjects apparently less sensitive and some actually more sensitive. This result contrasts with our observation on exercise, but is in accordance with the findings of study by Osterballe et al, ${ }^{12}$ who did not find changes in mean histamine threshold in six patients tested. Of the four subjects who participated in both parts of the study, all were less sensitive to exercise while breathing ionised air but three were more sensitive to histamine under these conditions. We are unable to explain the difference in response to exercise and histamine but do not believe that it is simply a manifestation of the reproducibility of the histamine challenge, since the types of test we used has generally been shown to give reproducible results. ${ }^{14}$

It is not clear how ions modulate the bronchial response to exercise. In the past the effect of ions was attributed to changing tissue serotonin concentrations, ${ }^{15}$ which could affect basal bronchial tone. Alternatively, it is now clear that heat loss via water evaporation from the respiratory mucosa is important in exercise-induced asthma, ${ }^{6}$ and since negative ions in a concentration similar to the one we used have been shown to slow the rate of fluid evaporation in vitro ${ }^{16}$ possibly air ionisation modifies heat loss from the mucosa. The measured respiratory heat loss for the control and ionised-air exercise challenges in this study (table 2) were, however, similar; so this suggestion seems unlikely to be correct. There may be a clue in the fact that ionisation clearly affected exercise-induced asthma but not histamine-induced asthma. Histamine is generally believed to work directly on the bronchial smooth muscle while exercise almost certainly evokes sev- 
eral processes, culminating in the release of stored chemical mediators. ${ }^{1-617}$

\section{References}

${ }^{1}$ Curry JJ. The action of histamine on the respiratory tract in normal and asthmatic subjects. J Clin Invest 1946;25:785-91.

${ }^{2}$ Makino S. Clinical significance of bronchial sensitivity to acetylcholine and histamine in bronchial asthma. $J$ Allergy 1966;38:127-42.

${ }^{3}$ Jones RS, Buston MH, Wharton MJ. The effect of exercise on ventilatory function in the child with asthma. Br J Dis Chest 1962;56:78-86.

${ }^{4}$ Boushey HA, Holtzman MJ, Sheller JR, Nadel JA. Bronchial hyperreactivity. Am Rev Respir Dis 1980;121:389-414.

5 Bar-Or O, Neuman I, Dotan R. Effects of dry and humid climates on exercise-induced asthma in children and adolescents. J Allergy Clin Immunol 1977;60:163-8.

- Deal EC, MacFadden ER, Ingram RH, Jaeger JJ. Role of respiratory heat exchange in production of exercise-induced asthma. J Appl Physiol 1979;46: 467-75.

${ }^{7}$ Krueger AP, Reed EJ. Biological impact of small air ions. Science 1976;193:1203-13.

${ }^{8}$ Winsor T, Beckett JC. Biological effects of ionized air in man. Am J Phys Med 1958;37:83-9.
' Badre R, Guillern R, Hee J. Study invitro of the action? of light atmospheric ions on the ciliary activity of the $\overrightarrow{\vec{F}}$ tracheal epithelium. Ann Pharm Fr 1966;24:469-78.

${ }^{10}$ Palti Y, De Nour E, Abrahamov A. The effects ofO atmospheric ions on the respiratory systems of infants. Pediatrics 1966;38:405-11.

"Jones DP, O'Conner SA, Collins JV, Watson BW. $\vec{\nabla}$ Effects of long term ionised air treatment on patients with bronchial asthma. Thorax 1976;31:428-32.

${ }^{12}$ Osterballe $O$, Weeke B, Albrechtsen $O$. Influence of small atmospheric ions on the airways in patients with. bronchial asthma. Allergy 1979;34:187-194.

${ }^{13}$ Chai H, Farr RS, Froehlich LA, Mathison DA, et al. Standardization of bronchial inhalation challenge pro-cedures. J Allergy Clin Immunol 1975;56:323-7.

14 Juniper EF, Frith PA, Dunett C, Cockcroft DW, Hargreave FE. Reproducibility and comparison of responses to inhaled histamine and methacholine. Thorax 1978;33:705-10.

is Kreuger AP, Smith RF. The biological mechanism of airo ion action: negative ion effect on the concentration and metabolism of 5HT in the mammalian respiratory tract. J Gen Physiol 1960;44:269-72.

${ }^{16}$ Hart FX, Bachman CH. The effect of air ions on liquide evaporation rates. Int J Biometeorol 1981;12:251-61. के

${ }^{17}$ Lee TH, Nagy L, Nagakura T, Walport MJ, Kay AB. Identification and partial characterisation of an exercise-induced neutrophil chemotactic factor in. bronchial asthma. J Clin Invest 1982;69:889-99. 